\title{
ANALISA METODE PROFILE MATCHING DALAM MENENTUKAN KELAYAKAN PEMBERIAN KREDIT KEPEMILIKAN RUMAH (KPR)
}

\author{
Teuku Radillah ${ }^{1}$, Leonard Tambunan ${ }^{2,}$ Budy Satria ${ }^{3,}$ Muhammad Iqbal $^{3}$, \\ ${ }^{1,2,3,4}$ Akademi Manajemen Informatika Dan Komputer (AMIK) Mitra Gama \\ Jl. Khayangan No 99 Kota Duri kode pos 28784 \\ e-mail :t.radillah@gmail.com, tambunan.leonard81@gmail.com, \\ budysatriadeveloper@gmail.com, iqbal.kun@gmail.com
}

\begin{abstract}
ABSTRAK
KPR (Kredit Kepemilikan Rumah) merupakan pembelian rumah secara kredit atau cicilan dengan jangka waktu dan suku bunga tertentu. Permasalahan yang Seringkali terjadi pada proses pemberian KPR adalah dalam memberikan analisa rekomendasi kelayakan rumah seperti kesalahan dalam menganalisa kredit sering menjadi menyebabkan pembayaran kredit macet, dan mengganggu sistem perputaran dana antara pencairan pemberian kredit dengan siklus piutang yang ditagihkan. Selain itu belum adaya filter dalam penentuan kelayakan pemberian kredit secara komputerisasi yang dilengkapi dengan sistem penunjang keputusan yang dapat mendeskripsikan faktor-faktor pendukung yang menjadi bobot perhitungan dalam pengambilan keputusan untuk menentukan kelayakan pemberian kredit rumah. Untuk menganalisa kelayakan pemberian KPR tersebut dibutuhkan suatu sistem pendukung keputusan untuk memberikan analisa yang baik dengan menggunakan metode profile matching sebagai acuan dalam memberikan keputusan kelayakan kredit rumah, dan dari implementasi metode profile matching ini menghasilkan analisa perhitungan yang akurat yaitu standar batas kelayakan ni (Nilai total aspek) harus diatas 2,7. Batas nilai tersebut merupakan parameter yang diperoleh dari akumulasi (penjumlahan) total nilai aspek (ni) terendah yang didapat dari bobot nilai kapasitas GAP, sehingga calon konsumen yang memperoleh diawah nilai batas tersebut akan dikategorikan tidak layak.
\end{abstract}

Kata kunci : Analisa KPR, Profile Matching

\begin{abstract}
KPR (Home Ownership Credit) is a home purchase on credit or in installments with a certain period and interest rate. The problem that often occurs in the process of providing mortgages is in providing a recommendation analysis of the feasibility of a house, such as errors in analyzing credit often causing bad credit payments, and disrupting the fund circulation system between the disbursement of credit and the cycle of receivables that are billed. In addition, there is no filter in determining creditworthiness in a computerized way that is equipped with a decision support system that can describe the supporting factors that become the weight of calculations in decision making to determine the feasibility of providing home loans. To analyze the feasibility of granting mortgages, a decision support system is needed to provide a good analysis using the profile matching method as a reference in making decisions on home credit worthiness
\end{abstract}

Keywords: KPR analysis, Profile Matching

\section{PENDAHULUAN}

Pesatnya pertumbuhan angka pengajuan kredit pinjaman rumah setiap bulannya memberikan dampak terhadap kinerja dan pelayanan dalam menganalisa kelayakan pemberian kredit pinjaman rumah (KPR). 
I N F O R M A I I A

Jurnal Informatika, Manajemen dan Komputer, Vol. 13 No. 1 , Mei 2021

eISSN : 2580-3042

pISSN : 1979-0694

Permasalahan yang Seringkali terjadi seperti kesalahan dalam menganalisa kredit dapat menyebabkan pembayaran kredit macet, dan mengganggu sistem perputaran dana antara pencairan pemberian kredit dengan siklus piutang yang ditagihkan. Selain itu, pada analisa KPR pada umumnya belum memiliki filter dalam penentuan kelayakan pemberian kredit secara komputerisasi yang dilengkapi dengan sistem penunjang keputusan yang dapat mendeskripsikan faktor-faktor pendukung yang menjadi bobot perhitungan dalam pengambilan keputusan untuk menentukan kelayakan pemberian kredit rumah seperti Status Kepemilikan Rumah, Bentuk Usaha, Penghasilan pokok, Penghasilan sampingan, Kemampuan pembayaran, serta agunan atau jaminan yang menjadi acuan penilaian kelayakan calon nasabah, dan dengan diterapkan metode profile matching dalam menganalisa suatu keputusan berdasarkan criteria yang telah ditentukan tersebut, dapat mengurangi angka kredit macet, dan calon nasabah yang didanai bear-benar layak mendapatkan pijaman dana untuk kepemilikan rumah.

\section{a. Tujuan dan Manfaat Penelitian}

1. Tujuan Penelitian

Adapun tujuan penelitian secara global yang dilakukan adalah sebagai berikut :

a. Memberikan keputusan yang akurat dalam menentukan kelayakan pemberian KPR.

b. Menciptakan sistem pendukung keputusan yang dapat menentukan kelayakan pemberian KPR berdasarkan kriteria yang telah ditentukan .

\section{Manfaat Penelitian}

Manfaat keilmuan dari hasil penelitian yang berjudul Analisa Metode Profile Matching Dalam Menentukan Kelayakan Pemberian Kredit Kepemilikan Rumah (KPR) ini adalah :

a. Memberikan kemudahan bagi manajemen leasing pemberian KPR dalam menyeleksi calon nasabah dalam proses pencairan KPR

b. Metode Profile Matching membantu dalam menganalisa kelayakan pengajuan KPR sehingga mengurangi angka kemacetan pemabayaran KPR.

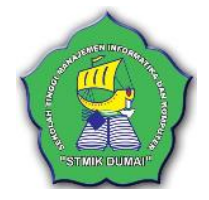

c. Sebagai bahan rujukan pengembangan keilmuan dalam bidang system pendukung keputusan yang memiliki studi kasus yang relevan

\section{a. Kredit}

Definisi kredit menurut undang-undang No 10 Tahun 1998 merupakan penyediaan uang atau tagihan yang dapat dipersamakan dengan itu berdasakan persetujuan atau kesepakatan pinjam meminjam antara bank dengan pihak lain yang mewajibkan pihak pinjaman untuk melunasi utangmyasetelah jangka waktu tertentu dengan pemebrian. Kredit adalah semua pinjaman yang harus dibayar kembali sesuai perjanjian yang disepakati oleh debitur dengan jumlahpinjaman beserta bunganya (Atmawati, 2015)

\section{b. Kredit Kepemilikan Rumah}

Kredit kepemilikan rumah merupakan kredt yang diberikan untuk membantu konsumen dalam memerlukan kebutuhan pribadi maupun keluarga yang bersifat komersial dan tidak memiliki nilai tambah barang atau jasa dimasyarakat.

\section{c. Sistem Informasi}

Sistem adalah sekelompok komponen dan elemen yang digabungkan menjadi satu untuk mencapai tujuan tertentu. Ssistem adalah elemen yang terintegrasi untuk mencapai tujuan organisasi atau perusahaan yang terdiri atas sejumlah sumber daya. Sistem merupakan sekelompok komponen dan elemn yang saling berhubungan dan bekerjasama untuk mencapai suatu tujuan (Indrajani, 2015).

Sistem informasi adalah suatu sistem didalam suatu organisasi yang mempertemukan kebutuhan, pengolahan transaksi harian yang mendukung fungsi operasi organisasi yang bersifat manajerial dengan kegiatan strategi dari suatu organisasi untuk dapat menyediakan laporan-laporan yang diperlukan oleh pihak luar tertentu (Sutabri, 2012)

\section{d. Sistem Penunjang Keputusan}

Sistem penunjang keputusan (SPK) atau Decision Support System (DSS) merupakan pasangan intelektual dari sumber daya manusia dengan kemampuan komputer untuk memperbaiki keputusan, yaitu sistem pendukung keputusan berbasis komputer bagi pembuat keputusan manajemen yang menghadapi masalah semi terstruktur.

DSS merupakan sistem informasi interaktif 
I N F O R M A I I A

Jurnal Informatika, Manajemen dan Komputer, Vol. 13 No. 1 , Mei 2021

eISSN : 2580-3042

pISSN : 1979-0694

yang menyediakan informasi pemodelan dan pemanipulasian data. Sistem itu digunakan untuk membantu pengambilan keputusan dalam situasi yang semi terstruktur dan situasi yang tidak terstruktur, di mana tak seorang pun tahu secara pasti bagaimana keputusan seharusnya dibuat (Priranda Widara Ananta \& Sri Winiarti, 2013)

\section{e. Kelayakan Pemberian Kredit}

Kredit berasal dari bahasa Yunani, yaitu "credere", yang berarti kepecayaan, sedangkan Kelayakan merupakan suatu proses penilaian suatu objek atau entitas melalui pertimbangan berbagai aspek sehingga objek atau entitas tersebut dapat disebut mampu dalam melakukan suatu. kelayakan pemberian kredit merupakan hasil suatu penilaian yang akan dicapai suatu perusahaan atau organisasi yang mencakupi kesanggupan atau kemampuan dalam pengembalian dana pinjaman. (Lapia et al., 2017). Adapun analisa pemberian kredit tersebut meliputi beberapa aspek, yaitu aspek hukum, aspek manajemen, aspek pemasaran, aspek teknis, aspek keuangan, dan aspek ekonomi

\section{f. Prinsip - prinsip Dalam Pemberian Kredit}

Analisa penilaian pemberian kredit sebagai berikut :

a. Pengembalian (return) adalah penilaian atas hasil yang akan dicapai perusahaan calon debitor setelah memperoleh kredit. Apakah hasil yang dicapai akan mampu digunakan untuk mengangsur pinjaman serta bersamaan dengan pengembalian pinjaman apakah usaha debitur dapat berkembang atau tidak.

b. Kemampuan pengembalian (Repayment capacity) adalah memperhitungkan jangka waktu pengembalian kredit yang sesuai dengan kemampuan pembayaran debitur.

c. Kemampuan menghadapi resiko (risk bearingability) adalah memperhitungkan besarnya kemampuan perusahaan calon debitur untuk menghadapi resiko, apakah perusahaan calon debitur resikonya besar sekali atau kecil. Kemampuan menghadapi resiko erat kaitannya dengan jaminan yang diberikan debitur apabila resiko kegagalan pembayaran terjadi. g. Aspek-aspek Penilaian Kelayakan Kredit

Analisa kredit dapat dirangkum dan secara singkat sebgai berikut :

a. Aspek hukum, tujuannya adalah untuk menilai kebenaran dan legalitas dokumendokumen persyaratan kredit. Dokumen dokumen persyaratan kredit yang tidak lengkap dan tidak akurat akan menimbulkan masalah yang mungkin merugikan kreditur.

b. Aspek pasar dan pemasaran, merupakan aspek untuk menilai apakah produk yang dipasarkan akan laku dipasar, wilayah pemasaran dan bagaimana strategi pemasaran yang dilakukan perusahaan.

c. Aspek Pasar dan pemasaran merupakan aspek untuk menilai apakah produk yang dipasarkan akan laku dipasar, wilayah pemasaran dan bagaimana strategi pemasaran yang dilakukan perusahaan.

Aspek keuangan, untuk menilai keuangan perusahaan yang dilihat dari laporan keuangan perusahaan

\section{METODOLOGI PENELITIAN}

Metodologi untuk pengembangan sistem merupakan proses standard yang digunakan team pengembang untuk menghubungkan semua langkah yang diperlukan untuk menganalisa, merancang, mengimplementasi, dan memelihara sistem informasi. Adapun metodologi yang sampai saat ini masih sesuai untuk menjadi pedoman dalam pengambilan keputusan adalah metose Profile Matching

\section{a. Metode Profile Matching}

Metode Profile Matching atau pencocokan profil adalah metode yang sering sebagai mekanisme dalam pengambilan keputusan dengan mengasumsikan bahwa terdapat tingkat variabel prediktor yang ideal yang harus dipenuhi oleh subjek yang diteliti, bukannya tingkat minimal yang harus dipenuhi atau dilewati (Defiariany, 2016)

Dalam proses profile matching diawali dengan pemiliahan kriteria yang dibutuhkan dan memberikan Nilai Target pada masingmasing Aspek. Tahap berikutnya perbandingan dilakukan antara kemampuan individu dengan kualifikasi yang telah ditetapkan sehingga didapatkan Gap dimana semakin kecil nilai yang didapatkan maka bobot nilai semakin besar (Awaliyah et al., 2020). Secara garis besar profile matching merupakan proses 


\section{INFORM T I K A}

Jurnal Informatika, Manajemen dan Komputer, Vol. 13 No. 1 , Mei 2021

eISSN : 2580-3042

pISSN : 1979-0694

membandingkan antara nilai data aktual dari suatu profil yang akan dinilai dengan nilai profil yang diharapkan, sehingga dapat diketahui perbedaan kompetensinya (disebut juga gap), semakin kecil gap yang dihasilkan maka bobot nilainya semakin besar yang berarti memiliki peluang lebih besar untuk direkomendasikan untuk kelayakan pemberian kredit rumah.

beberapa tahapan dan perumusan perhitungan dengan metode profile matching adalah sebagai berikut:

1. Pembobotan

Pada tahap ini, akan ditentukan bobot nilai masing-masing aspek dengan menggunakan bobot nilai yang telah ditentukan bagi masing-masing aspek itu sendiri. Adapun inputan dari proses pembobotan ini adalah selisih dari profil calon customer peminjam dengan profil calon customer layak diberi pinjaman yang diinginkan. Dalam penentuan peringkat pada aspek penghasilan, tanggungan, dan aspek jaminan

2. Perhitungan dan Pengelompokkan Core Factor dan Secondary Factor.

Setelah menentukan bobot nilai gap untuk ketiga aspek yang dibutuhkan, kemudian tiap aspek dikelompokkan lagi menjadi 2 kelompok yaitu core factor dan secondary factor (Barang et al., 2016).

a. Core Factor ( Faktor Utama )

Core factor merupakan aspek (kompetensi) yang paling menonjol/paling dibutuhkan oleh suatu jabatan yang diperkirakan dapat menghasilkan kinerja optimal. Untuk Menghitung core factor digunakan rumus :

Keterangan :

$$
\underset{\mathbf{N C F}}{=}=\frac{\Sigma \mathbf{N C}}{\Sigma \mathbf{I C}}
$$

$\mathrm{NCF}=$ Nilai rata-rata core factor

$\mathrm{NC}=$ Jumlah total nilai core factor

$\mathrm{IC}=$ Jumlah item core factor

b. Secondary Factor ( Faktor Pendukung )

Secondary factor adalah item-item selain aspek yang ada pada core factor (Muqtadir \& Purdianto, 2013). Untuk menghitung secondary factor digunakan rumus :

$$
\mathbf{N S F}=\frac{\boldsymbol{\Sigma} \mathbf{N S}}{\Sigma \mathrm{IS}}
$$

$\mathrm{NSF}=$ Nilai rata-rata secondary factor

NS = Jumlah total nilai secondary factor
IS = Jumlah item secondary factor

Rumus di atas adalah rumus untuk menghitung core factor dan secondary factor dari aspek penghasilan. Rumus di atas juga digunakan untuk menghitung core factor dan secondary factor dari aspek tanggungan dan aspek jaminan.

3. Perhitungan Nilai Total Tiap Aspek

Dari perhitungan core factor dan secondary factor dari tiap-tiap aspek, kemudian dihitung nilai total dari tiap-tiap aspek yang diperkirakan berpengaruh pada kinerja tiap-tiap profile. Untuk menghitung nila total dari masing- masing aspek, digunakan rumus :

$\mathrm{N}=40 \% \mathrm{NC}+60 \% \quad \mathrm{NSc}$

Keterangan :

$\mathrm{N} \quad=$ Nilai Total Tiap Aspek

$\mathrm{NC}=$ Nilai Core Factor

$\mathrm{NSc} \quad=$ Nilai Secondary Factor

\section{b. Kriteria Penilaian}

Bedasarkan criteria yang sidah ditentukan, maka dilakukan langkah-langkah berdasarkan Metode Profile Matching yaitu sebagai berikut :

1. Penilaian nilai pada setiap criteria (value Target).

2. Pembobotan nilai $G A P$

3. Perhitungan core factor

4. Perhitungan secondary factor

5. Perhitungan nilai toatal

6. Perhitungan ranking

Adapun skala ordinal pada pembobotan criteria (value target) untuk asing-masing kriteria (Apriana, 2016) sebagai berikut :

1. Sangat kurang

2. Kurang

3. Cukup

4. Baik

5. Sangat baik

\section{HASIL DAN PEMBAHASAN}

a. Hasil Analisa Proses

Untuk merancang suatu system keputusan menggunakan metode profile matching dibutuhkan bobot dan pembobotan kriteria (value target) tersebut dapat dilihat pada Tabel 1. Bobot Kriteria 
INFORM T I K

Jurnal Informatika, Manajemen dan Komputer, Vol. 13 No. 1 , Mei 2021

eISSN : 2580-3042

pISSN : 1979-0694

Tabel 1. Bobot

\begin{tabular}{lc}
\hline \multicolumn{1}{c}{ Kriteria } & Nilai \\
\hline Sangat Kurang & 1 \\
\hline Kurang & 2 \\
\hline Cukup & 3 \\
\hline Baik & 4 \\
\hline Sangat Baik & 5 \\
\hline
\end{tabular}

Tabel 2. Bobot Kriteria

\begin{tabular}{llc}
\hline No & \multicolumn{1}{c}{ Kriteria } & $\begin{array}{c}\text { Value } \\
\text { Target }\end{array}$ \\
\hline 1 & $\begin{array}{l}\text { Status Kepemilikan Rumah } \\
(\mathrm{C} 1)\end{array}$ & 5 \\
\hline 2 & Bentuk Usaha (C2) & 3 \\
\hline 3 & Penghasilan pokok (C3) & 4 \\
\hline 4 & Penghasilan sampingan (C4) & 4 \\
\hline 5 & $\begin{array}{l}\text { Kemampuan pembayaran } \\
\text { (C5) }\end{array}$ & 4 \\
\hline 6 & Agunan atau jaminan (C6) & 3 \\
\hline
\end{tabular}

\section{b. Pemetaan GAP}

Pemetaan GAP yang dimaksud pada pembahasan ini adalah perbedaan kriteria yang dimiliki seseorang dengan criteria yang diinginkan pengguna sesuai dengan aspek penilaian formula dengan pemetaan GAP tersebut dapat dilihat pada persamaan GAP = Kriteria calon nasabah - Kriteria yang diinginkan.Sedangkan perhitungan GAP lainnya yang terjadi itu sendiri pada setiap aspeknya memiliki perhitungan yang berbedabeda (Dimandili et al., 2018)

Tabel 3 Penentuan nilai bobot sebagai

\begin{tabular}{lcclr}
\hline No & Selisih & $\begin{array}{c}\text { Bobot } \\
\text { Nilai }\end{array}$ & \multicolumn{2}{c}{ Keterangan } \\
\hline 1 & 0 & 5 & $\begin{array}{l}\text { Kompetensi } \\
\text { sesuai dengan } \\
\text { dibutuhkan }\end{array}$ & yang \\
\hline 2 & 1 & 4,5 & $\begin{array}{l}\text { Kompetensi individu } \\
\text { kelebihan } \\
\text { tingakat/level }\end{array}$ & 1 \\
\hline 3 & -1 & 4 & $\begin{array}{l}\text { Kompetensi individu } \\
\text { kekurangan } \\
\text { tingakat/level }\end{array}$ \\
\hline 4 & 2 & 3,5 & $\begin{array}{l}\text { Kompetensi individu } \\
\text { kelebihan } \\
\text { tingakat/level }\end{array}$ \\
\hline 5 & -2 & 3 & $\begin{array}{l}\text { Kompetensi individu } \\
\text { kekurangan } \\
\text { tingakat/level }\end{array}$ \\
\hline & & & & 2
\end{tabular}

\begin{tabular}{llll}
\hline 6 & 3 & 2,5 & \multicolumn{2}{l}{$\begin{array}{l}\text { Kompetensi individu } \\
\text { kelebihan } \\
\text { tingakat/level }\end{array}$} \\
\hline 7 & -3 & 2 & $\begin{array}{l}\text { Kompetensi individu } \\
\text { kekurangan } \\
\text { tingakat/level }\end{array}$ \\
\hline 8 & 4 & 1,5 & $\begin{array}{l}\text { Kompetensi individu } \\
\text { kelebihan } \\
\text { tingakat/level }\end{array}$ \\
\hline 9 & -4 & 1 & $\begin{array}{l}\text { Kompetensi individu } \\
\text { kekurangan } \\
\text { tingakat/level }\end{array}$ \\
\hline
\end{tabular}

Tabel 4 Bobot Aspek Sub Kriteria

\begin{tabular}{|c|c|c|c|c|}
\hline No & Selisih & $\begin{array}{l}\text { Val } \\
\text { ue } \\
\text { Tar } \\
\text { get }\end{array}$ & Sub ASpek & $\begin{array}{c}\text { Nilai } \\
\text { Bobo } \\
\text { t }\end{array}$ \\
\hline \multirow[t]{5}{*}{1} & \multirow{5}{*}{$\begin{array}{l}\text { Status } \\
\text { Kepemili } \\
\text { kan } \\
\text { Rumah }\end{array}$} & \multirow[t]{5}{*}{5} & $\begin{array}{l}\text { Milik } \\
\text { Sendiri }\end{array}$ & 5 \\
\hline & & & $\begin{array}{l}\text { Milik Orang } \\
\text { Tua }\end{array}$ & 4 \\
\hline & & & $\begin{array}{l}\text { Milik } \\
\text { Saudara } \\
\text { Kandung } \\
\end{array}$ & 3 \\
\hline & & & Kontarak & 2 \\
\hline & & & sewa & 1 \\
\hline \multirow[t]{5}{*}{2} & \multirow{5}{*}{$\begin{array}{l}\text { Bentuk } \\
\text { Usaha }\end{array}$} & \multirow[t]{5}{*}{3} & Permanen & 5 \\
\hline & & & $\begin{array}{l}\text { Semi } \\
\text { Permanen }\end{array}$ & 4 \\
\hline & & & $\begin{array}{l}\text { Tidak } \\
\text { Tetap/berger } \\
\text { ak }\end{array}$ & 3 \\
\hline & & & Musiman & 2 \\
\hline & & & $\begin{array}{ll}\text { Tidak ada } \\
\text { usaha }\end{array}$ & 1 \\
\hline \multirow[t]{5}{*}{3} & \multirow{5}{*}{$\begin{array}{l}\text { Penghasi } \\
\text { lan } \\
\text { pokok }\end{array}$} & & $>15$ Juta & 5 \\
\hline & & & $\begin{array}{l}>10<=15 \\
\text { Juta }\end{array}$ & 4 \\
\hline & & & $\begin{array}{lll}>7 & <=10 \\
\text { Juta } & & \\
\end{array}$ & 3 \\
\hline & & & $>5<=7$ Juta & 2 \\
\hline & & & $<5$ Juta & 1 \\
\hline \multirow[t]{5}{*}{4} & \multirow{5}{*}{$\begin{array}{l}\text { Penghasi } \\
\text { lan } \\
\text { sampinga } \\
\mathrm{n}\end{array}$} & & $>15$ Juta & 5 \\
\hline & & & $\begin{array}{l}>10<=15 \\
\text { Juta }\end{array}$ & 4 \\
\hline & & & $\begin{array}{l}>7<=10 \\
\text { Juta }\end{array}$ & 3 \\
\hline & & & $>5<=7$ Juta & 2 \\
\hline & & & $<5$ Juta & 1 \\
\hline \multirow[t]{2}{*}{5} & \multirow{2}{*}{$\begin{array}{l}\text { Kemamp } \\
\text { uan } \\
\text { pembaya }\end{array}$} & \multirow[t]{2}{*}{4} & $>10$ Juta & 5 \\
\hline & & & $\begin{array}{lll}>7 & <=10 \\
\text { Juta } & & \\
\end{array}$ & 4 \\
\hline
\end{tabular}


I N F ORM A T I R

Jurnal Informatika, Manajemen dan Komputer, Vol. 13 No. 1 , Mei 2021

eISSN : 2580-3042

pISSN : 1979-0694

\begin{tabular}{|c|c|c|c|c|}
\hline & \multirow[t]{3}{*}{ ran } & & \multicolumn{2}{|l|}{$>5<=7$ Juta } \\
\hline & & & $>3<=5$ Juta & 2 \\
\hline & & & $<3$ Juta & 1 \\
\hline \multirow[t]{5}{*}{6} & \multirow{5}{*}{$\begin{array}{l}\text { Agunan } \\
\text { atau } \\
\text { jaminan }\end{array}$} & \multirow[t]{5}{*}{3} & $\begin{array}{l}\text { Rumah } \\
\text { Sertifikat }\end{array}$ & 5 \\
\hline & & & $\begin{array}{l}\text { Rumah } \\
\text { SKGR }\end{array}$ & 4 \\
\hline & & & $\begin{array}{l}\text { Sertifikat } \\
\text { Tanah }\end{array}$ & 3 \\
\hline & & & $\begin{array}{l}\text { Surat Tanah } \\
\text { SKGR }\end{array}$ & 2 \\
\hline & & & $\begin{array}{l}\text { BPKB } \\
\text { Mobil }\end{array}$ & 1 \\
\hline
\end{tabular}

\section{c. Analisa Perhitungan Metode Profile Matching}

Pada analisa perhitungan metode profile matching setiap calon yang telah mendapatkan nilai bobot aspek sub kriteria selanjutnya ditentukan pembobotan nilai GAP yang dapat dilihat pada Tabel 3.Pembobotan Nilai GAP

\begin{tabular}{|c|c|c|c|c|c|c|c|}
\hline \multirow[t]{3}{*}{ No } & \multicolumn{7}{|c|}{ Aspek } \\
\hline & Nasabah & $\mathrm{C}$ & $\mathrm{C}$ & $\mathrm{C}$ & $\mathrm{C}$ & $\mathrm{C}$ & $\mathrm{C}$ \\
\hline & $\begin{array}{c}\text { (Pemohon } \\
\text { Kredit) }\end{array}$ & 1 & 2 & 3 & 4 & 5 & 6 \\
\hline \multicolumn{8}{|c|}{ Value Target } \\
\hline & & 5 & 3 & 4 & 4 & 4 & 5 \\
\hline 1 & Aryan & 4 & 4 & 4 & 3 & 4 & 4 \\
\hline 2 & Aura & 2 & 2 & 4 & 2 & 3 & 3 \\
\hline 3 & Rabbaim & 1 & 1 & 1 & 1 & 2 & 2 \\
\hline No & \multicolumn{7}{|c|}{ Profile Nasabah } \\
\hline 1 & Aryan & -1 & 1 & 0 & $\begin{array}{l}- \\
1\end{array}$ & 0 & -1 \\
\hline 2 & Aura & -3 & $\begin{array}{l}- \\
1\end{array}$ & 0 & - & -1 & -2 \\
\hline 3 & Rabbaim & -4 & $\overline{2}$ & -3 & - & -2 & -3 \\
\hline
\end{tabular}

Tabel 5.Penentuan Bobot Nasabah

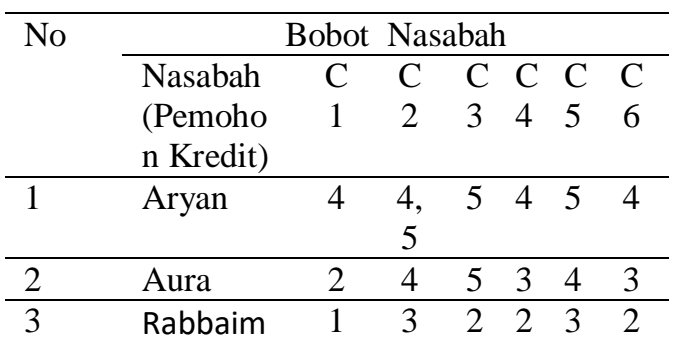

\section{d. Perhitungan nilai Core Factor}

$$
N C F=\frac{\sum N C(i, s, p)}{\sum I C}
$$

1. Aryan :

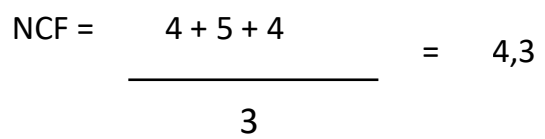

$\mathrm{NSF}=\frac{4,5+4+5}{3}=4,5$

(X) \%NCF(i,s,p) + (X) \%NSF(i,s,p) $=N(i, s, p)$

$\mathrm{NCF}=60 \%(4,33)+40 \%(4,5)=4,39$

2. Aura :

$\mathrm{NCF}=\frac{2+5+3}{3}=3,33$

$\mathrm{NSF}=\frac{4+3+4}{3}=3,66$

$(X) \% N C F(i, s, p)+(X) \% N S F(i, s, p)=N(i, s, p)$

$\mathrm{NCF}=60 \%(3,33)+40 \%(3,66)=3,46$

3. Rabbaim :

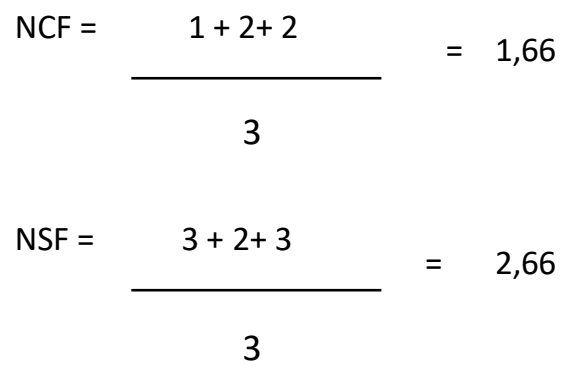

(X) \%NCF(i,s,p) + (X) \%NSF(i,s,p) $=\mathrm{N}(i, s, p)$

$N C F=60 \%(1,66)+40 \%(2,66)=2,06$

Pada perhitungan studi kasus diatas, calon nasabah untuk nama Rabbaim tidak layak diberikan pinjaman kredit. Adapun standar batas kelayakan ni (Nilai total aspek) harus diatas 2,7. Batas nilai tersebut diperoleh dari akumulasi(penjumlahan) total nilai aspek (ni) terendah yang didapat dari bobot nilai kapasitas $G A P$ 
INFORMA TIK A

Jurnal Informatika, Manajemen dan Komputer, Vol. 13 No. 1 , Mei 2021

eISSN : 2580-3042

pISSN : 1979-0694

\section{e. Hasil Implementasi}

Implementasi merupakan proses untuk mewujudkan system yang dirancang. Urutan dari proses implementasi adalah urutan dari kegiatan desain/perancangan sampai kegiatan output/laporan yang dilakukan dalam mewujudkan sistem yang dirancang. Untuk mewujudkan sistem tersebut dibutuhkan dukungan komponen-komponen dalam implementasi terhadap sistem yang digunakan, seperti kebutuhan komponen hardware dan software. Adapun hasil implementasi analisa dari penerapan metode profile matching dalam menentukan kelayakan pemberian KPR sebagai berikut :

1. Untuk analisa calon nasabah dapat dilakukan dengan variable GAP dengan menampilkan No KTP calon nasabah, selanjutnya data nasabah akan tampil berdasarkan bobot sub kriteria, sehingga secara otomatis akan menghitung nilai GAP calon nasabah .

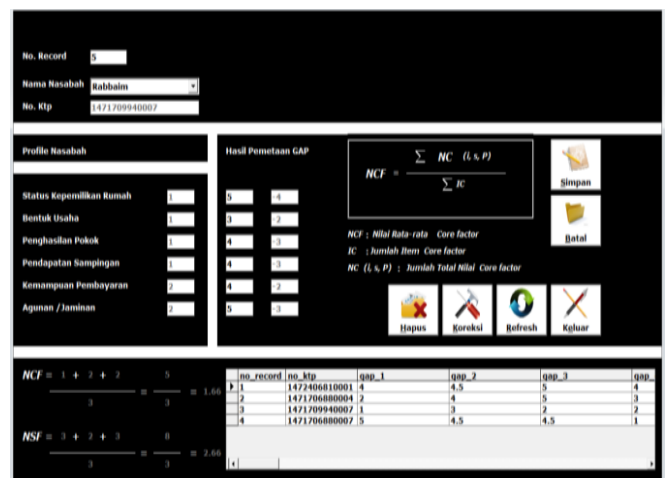

Gambar 1. Penilaian GAP

Pada aplikasi system pendukung berbasis metode profile matching akan menampilkan hasil perhitungan analisa kelayakan berdasarkan hasil perhitungan nilai Core factor dan Secondary Factor

2. Hasil Perhitungan Core dan Secondary Factor

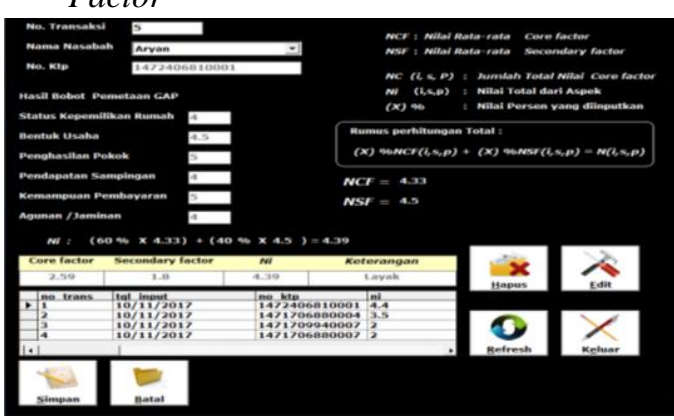

Gambar 2. Core/Secondary Factor

3. Hasil Kelayakan

Ni : $(60 \% \times 4.33)+(40 \% \times 4.5)=4.39$

\begin{tabular}{|c|c|c|c|}
\hline Core factor & \multicolumn{1}{c}{ Secondary factor } & \multicolumn{1}{c}{$\mathrm{Ni}$} & \multicolumn{1}{c|}{ Keterangan } \\
\hline 2.59 & 1.8 & 4.39 & Layak \\
\hline
\end{tabular}

$\mathrm{Ni}: \quad(60 \% \times 1.66)+(40 \% \times 2.66)=2.06$

\begin{tabular}{|c|c|c|c|}
\hline Core factor & \multicolumn{1}{c}{ Secondary factor } & \multicolumn{1}{c|}{$\mathrm{Ni}$} & \multicolumn{1}{c|}{ Keterangan } \\
\hline 0.99 & 1.06 & 2.05 & Tidak Layak \\
\hline
\end{tabular}

Gambar 3. Tampilan Hasil Kelayakan

Pada tampilan hasil perhitungan core/secondary factor secara otomatis akan menampilkan perhitungan hasil analisa kelayakan pada pemberian kredit KPR

\section{KESIMPULAN}

Dari uraian tersebut yang telah dibahas sebelumnya dapat ditarik kesimpulan sebagai berikut :

1. Berdasarkan penerapan metode profile matching yang dilakukan menghasilkan analisa perhitungan yang akurat yaitu standar batas kelayakan $n i$ (Nilai total aspek) harus diatas 2,7. Batas nilai tersebut diperoleh dari akumulasi (penjumlahan) total nilai aspek (ni) terendah yang didapat dari bobot nilai kapasitas GAP.

2. Implementasi algoritma metode profile matching pada aplikasi system pendukung keputusan memberikan kemudahan dalam menentukan kelayakan KPR pada calon nasabah. 
IN F O R M A T I A

Jurnal Informatika, Manajemen dan Komputer, Vol. 13 No. 1 , Mei 2021

eISSN : 2580-3042

pISSN : 1979-0694

3. Metode profile matching dapat dijadikan parameter atau tolak ukur dalam acuan pembuat system atau aplikasi pendukung keputusan bedasarkan kriteria dan pembobotan.

\section{REFERENSI}

Apriana, V. (2016). Penerapan Metode Profile Matching Untuk Menentukan Kelayakan Pemberian Pinjaman Pada Bank Perkreditan Rakyat. Moneter.

Atmawati, N. (2015). ANALISIS PEMBERIAN KREDIT PEMILIKAN RUMAH (KPR) DALAM RANGKA MENGURANGI NON PERFORMING LOAN (Studi pada PT. Bank Central Asia Tbk. Cabang Kediri). Jurnal Administrasi Bisnis S1 Universitas Brawijaya.

Awaliyah, M. M., Kurniawati, A., \& Rizana, A. F. (2020). Profile matching for students specialization in industrial engineering major. IOP Conference Series: Materials Science and Engineering.

https://doi.org/10.1088/1757899X/830/3/032063

Barang, P., Masitoh, E., \& Suhendar, A. (2016). Penerapan Metode Profile Matching Dalam Pengembangan Aplikasi E-Commerce Pada. Jurnal Sistem Informasi.

Defiariany. (2016). SISTEM PENDUKUNG KEPUTUSAN PEMILIHAN MAHASISWA BERPRESTASI MENGGUNAKAN METODE PROFILE MATCHING PADA STMIK INDONESIA PADANG. Jurnal Teknologi Informasi \& Pendidikan.

Dimandili, A., Purwandari, E. P., \& Efendi, R. (2018). PEMILIHAN INDEKOS MAHASISWA DAN PEMETAAN TINGKAT KRIMINALITAS DENGAN PROFILE MATCHING METHOD. Pseudocode.

https://doi.org/10.33369/pseudocode.5.1. $18-28$

Indrajani. (2015). Database Systems All in One Theory, Practice, and Case Study. In Database Systems All in One Theory, Practice, and Case Study. https://doi.org/718051154

Lapia, S., Dzulkirom AR, M., \& Zahroh Z. A,

Z. (2017). ANALISIS KELAYAKAN PEMBERIAN KREDIT USAHA MIKRO DALAM UPAYA MENGANTISIPASI TERJADINYA KREDIT BERMASALAH (Studi Kasus pada PT. Bank Rakyat Indonesia Unit Sawojajar Malang). Jurnal Administrasi Bisnis S1 Universitas Brawijaya.

Muqtadir, A., \& Purdianto, I. (2013). Sistem Pendukung Keputusan Kenaikan Jabatan Menggunakan Metode Profile Matching (Studi Kasus di PT. Industri Kemasan Semen Gresik). Teknik Informatika, Universitas PGRI Ronggolawe.

Priranda Widara Ananta, \& Sri Winiarti. (2013). Sistem Pendukung Keputusan Dalam Penilaian Kinerja Pegawai Untuk Kenaikan Jabatan Pegawai Menggunakan Metode Gap Kompetisi. Jurnal Sarjana Teknik Informatika EISSN : 2338-5197.

Sutabri, T. (2012). Konsep Sistem Informasi. Jurnal Administrasi Pendidikan UPI. 